\title{
MEMÓRIA E NARRADO: EXPERIÊNCIAS DE UM “AGITADOR SOCIAL"
}

\author{
Alessandra Bittencourt Flach ${ }^{1}$ \\ A lembrança é somente um príncipe encantado, \\ que desperta, um momento, a Bela-Adormecida- \\ no-Bosque de nossas histórias sem palavras. \\ (Michel de Certeau)
}

Este artigo pretende ser uma reflexão sobre a memória, especificamente no que se refere àquilo que ela tem de representativo da subjetividade e da identidade do sujeito em sua relação com o mundo. Para tanto, toma-se como pressuposto que essa memória se constitui na/pela narrativa, como explica Ecléa Bosi (1994: 68): "A narração da própria vida é o testemunho mais eloquente dos modos que a pessoa tem de lembrar. É a sua memória".

As questões aqui propostas não são, a priori, emergentes de um trabalho especializado no campo da antropologia, são, antes, parte de um projeto de pesquisa em andamento na área de Letras, mas que, diante da complexidade e especificidade do "objeto" de estudo, ampara-se, em grande medida, no referencial teórico e no suporte da antropologia. Isso se deve ao fato de que, por não se lidar com um texto escrito, produto acabado da autoria de um sujeito, optou-se por analisar um texto em construção e modificação, mediado pela interação entre o sujeito que fala e aqueles a quem se dirige.

O foco pretendido é analisar as entrevistas (ocorridas em encontros semanais de 2006 a 2009) de José Carlos do Santos, o Beleza, morador do bairro Restinga, periferia de Porto Alegre (Figura 1). A partir de seu discurso, predominantemente autobiográfico, é possível perceber como ele se vê como indivíduo em constante intervenção na sociedade, como transmissor de bens simbólicos (Barros, 1989: 36), seja através do testemunho de vida familiar (narrando seus métodos de educação dos filhos, valores, infância), seja através das narrativas de seus projetos sociais (como professor, conselheiro tutelar, líder comunitário).

\footnotetext{
${ }^{1}$ Universidade do Vale do Rio dos Sinos, Brasil.
} 


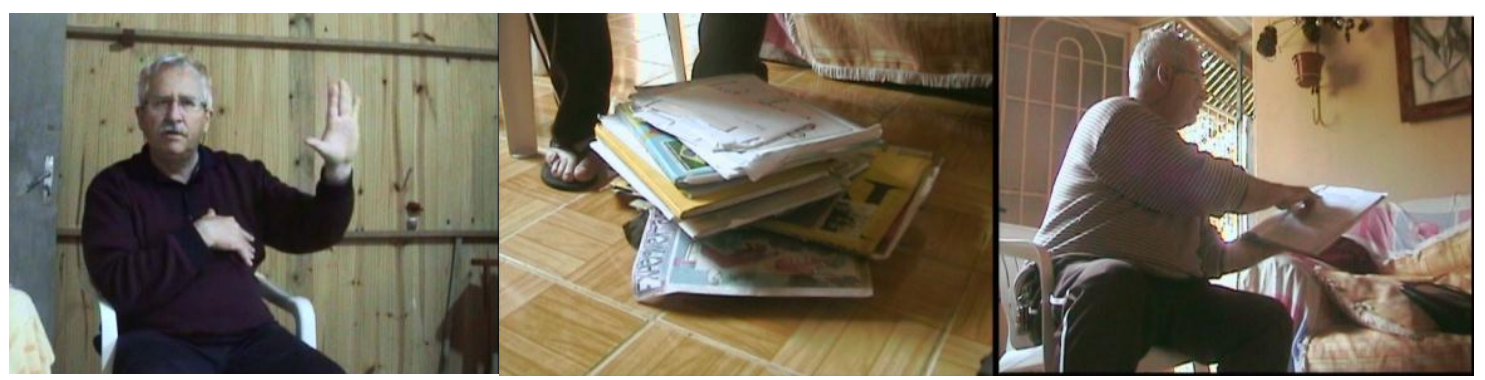

Figura 1: José Carlos dos Santos (Beleza), sua performance, seus guardados, sua casa.

Ao mesmo tempo em que refaz sua trajetória de vida através do seu relato reflexivo, o faz de uma forma a construir uma narrativa poética, no sentido de imprimirlhe um caráter estético com vistas a impressionar/comover/convencer os ouvintes. Clara é, no entanto, a noção referida por Gilberto Velho de que:

\begin{abstract}
A memória é fragmentada. O sentido de identificação depende em grande parte da organização desses pedaços, fragmentos de fatos e episódios separados. $\mathrm{O}$ passado, assim, é descontínuo. A consistência e o significado desse passado e da memória articulam-se à elaboração de projetos que dão sentido e estabelecem continuidade entre esses diferentes momentos e situações. (Velho, 1999: 103)
\end{abstract}

Ao organizar os "pedaços" de sua história de vida em texto a ser transmitido e arquitetado na presença dos pesquisadores, Beleza, ao mesmo tempo, revisita seu passado através de um exercício de recriação deste pela narrativa e projeta expectativas sobre vários aspectos - sociedade, política, saúde, educação -, tem um olhar para o futuro. Seu discurso, biográfico e memorialista, é quase como um manifesto, ou seja, é a sua forma particular e pessoal de agir sobre o mundo.

O que este senhor de 60 anos busca, diante do interesse dos pesquisadores em ouvir e registrar sua fala, é construir uma narrativa coesa, ainda que não linear, rica em imagens e representações, de certa forma uma espécie de estetização da memória. Sua memória, permeada da memória coletiva (Halbwachs, 2006), parte sempre de uma reflexão sobre o presente, sobre um fato do momento, para tensionar o passado, trazê-lo ao presente. Para tanto, seleciona, adapta, omite e repete fatos segundo critérios 
próprios. Há, portanto, que se analisar, também, aquilo que Pollak (1989) referiu como "zonas de sombra", os não-ditos.

Aquilo que se pretende fazer neste breve artigo dialoga com o projeto de pesquisa A vida Reinventada: Pressupostos Teóricos para Análise e Criação de Acervo de Narrativas Orais $(\mathrm{CNPq})$, coordenado pela Profa. Dra. Ana Lúcia Liberato Tettamanzy, do Programa de Pós-Graduação em Letras da UFRGS. A partir da gravação em vídeo de narrativas (sobre temas diversos, mas principalmente histórias de vida), visa-se criar um repositório digital destas, para acesso amplo ${ }^{2}$. Por intermédio desse projeto, chegou-se ao bairro Restinga, o qual é bastante diversificado e cuja “identidade" é marcada por muitos estereótipos (de parte da mídia, dos próprios moradores, das lideranças sociais). Com o intuito de registrar as histórias da constituição do bairro (em um processo de remoção do centro da cidade para a periferia na década de 1970) a partir da visão de seus moradores, alguns destes se tornaram mais próximos do grupo, desde 2006, com encontros regulares na casa do Beleza, justamente o narrador que servirá de análise aqui.

Desses encontros resultaram cerca de 40 horas de filmagens, não editadas, e registros escritos das entrevistas. A partir desse material, o grupo de pesquisa, em associação com alguns desses moradores, editou vídeos sobre os fazeres e práticas sociais da Restinga, principalmente a partir de uma perspectiva memorialista por parte dos entrevistados. Os vídeos retornam à comunidade, através de exposições em escolas e discussões com alunos e professores.

Paralelamente a esse projeto, percebeu-se que as narrativas de vida de Beleza constituíam um corpus de análise que não poderia ser ignorado, pela riqueza de detalhes e reflexões com que narrava suas experiências. O que será abordado neste artigo não são documentários, no sentido de vídeos editados e coesos, mas informações registradas em vídeo e nos diários de campo que enfatizam o percurso de vida e os projetos desse senhor, consideradas relevantes para entender seu processo de formação como indivíduo.

Em síntese, por se acreditar no ato de narrar como um meio de constituição do sujeito e como um exercício de criação estética e intervenção social que envolve considerar, inclusive, a presença do outro na organização do discurso, é que se percebe a pertinência de estudar narradores (hoje em dia tão escassos, pois, segundo Benjamin,

${ }^{2}$ Através do site www.ufrgs.br/vidareinventada.

Iluminuras, Porto Alegre, v.12, n. 29, p. 164-178, jul./dez. 2011 166 
1994, p.197, "são cada vez mais raras as pessoas que sabem narrar devidamente") como o Beleza, que faz da sua narrativa uma intervenção no mundo e uma reconfiguração de si mesmo, um herói épico, já que "a memória é a mais épica de todas as faculdades" (Benjamin, 1994: 210). Não sendo possível (nem funcional) estabelecer um comparativo entre o narrado e os fatos, dado o caráter naturalmente fragmentado e tendencioso da memória, é relevante tentar entender como esse discurso se metamorfoseia em narrativa e como a memória do sujeito se articula em texto.

\section{Personalidade encenada}

Como já referido, este artigo não partiu, a priori, de um interesse de pesquisa focado em descrever como moradores de um bairro da periferia da cidade organizam suas histórias de vida em narrativa. Antes, pretendia-se fazer um estudo (sob a perspectiva literária) sobre as várias versões de histórias (fantásticas e/ou relacionadas à fundação do bairro) contadas pelos moradores da Restinga. Entretanto, com o avanço desses estudos, ficaram muito evidentes dois aspectos: 1) um dos moradoresinformantes destacava-se em seu interesse e entusiasmo para contar histórias e "opinar" sobre os mais diversos assuntos; 2) percebeu-se uma clara predominância de narrativas em que ele era o centro da contenda, o "solucinador" de celeumas de toda ordem. Por conta disso, apresentou-se um novo horizonte de análise, mais voltado para os aspectos constitucionais das narrativas deste sujeito.

A partir da análise dos diários de campo (meus e de colegas pesquisadores) e da observação dos vídeos, percebeu-se que Beleza, um intenso articulador de ideais e críticas a toda manifestação de poder e entidade social de intenção duvidosa (segundo critérios dele), principalmente no que compete a poderes institucionalizados (governo, escola, igreja, universidade, projetos sociais, organizações comunitárias), ao abordar essas questões, sempre recorria a um episódio de sua vida para melhor ilustrar como deveria ser, como poderia ser diferente. Ou seja, sua história de vida foi sendo "construída" diante dos pesquisadores, ao longo de três anos, sob um viés claramente autoelogioso, ainda que disfarçado sob um discurso encoberto sob falsa modéstia.

Mais adiante, será abordado o processo de registro e o espaço em que as entrevistas se constituíram. Por ora, basta referir que os encontros eram para ele a oportunidade de expressar-se e expressar suas visões de mundo a interlocutores interessados, com a atenção e a escuta voltadas para ele, o que não tinha muito nem em 
casa nem entre os vizinhos. Conforme depoimento de dona Leonor, esposa de Beleza, ele espera ansiosamente pelos encontros, os quais, segundo ela, são uma distração de seus problemas de saúde e de suas frustrações com a situação do bairro. Ainda que, eventualmente, mais moradores participem das reuniões, Beleza sempre coordena as discussões, em uma atitude de fala direcionada aos seus interlocutores e, também, aos futuros espectadores, uma vez que faz longas digressões focando a câmera.

Com base em tais observações, pode-se perceber que estamos diante de uma personalidade encenada, tal como refere Erving Goffman (1999: 230-231):

\begin{abstract}
A noção geral de que fazemos uma representação de nós mesmos para os outros não é nenhuma novidade. $\mathrm{O}$ que deveria ser acentuado, para concluir, é que a própria estrutura do "eu" pode ser considerada segundo o modo como nos arranjamos para executar estas representações na nossa sociedade anglo-americana.

Neste trabalho, o indivíduo foi implicitamente dividido em dois papéis fundamentais: foi considerado como ator, um atormentado fabricante de impressões envolvido na tarefa demasiado humana de encenar uma representação; e foi considerado como personagem, como figura, tipicamente uma figura admirável, cujo espírito, força e outras excelentes qualidades a representação tinha por finalidade evocar.
\end{abstract}

Beleza, ator e personagem da própria história, compartilha uma série de experiências distintas no tempo e no espaço, todas as quais, no entanto, convergindo para a representação de um sujeito que se define à medida que refaz sua trajetória. Toda a sua narrativa de vida, permeada por uma série de outras intervenções (comentários e divagações dos interlocutores, vizinho que chama no portão da casa, desvios de assuntos, distanciamentos no tempo), sempre retoma a temática da constituição desse sujeito pela lembrança de episódios que exaltam as atitudes dessa "figura admirável".

Ao longo dos depoimentos e registros, e levando em consideração o período de convivência com Beleza, é possível resumir sua história de vida, mesmo que sabidamente incompleta e de modo insuficiente, da seguinte forma: José Carlos dos Santos, 60 anos, nasceu em Santo Antônio da Patrulha. Passou parte da infância e a adolescência em Osório. Teve dos avós o incentivo para ler e ser curioso das coisas do mundo. A avó recomendava: "Tem que escutar as pessoas" (Registro Audiovisual. 18 set. 2006). Ao chegar a Porto Alegre, morou em várias regiões (Zona Norte, Zona Leste). Acompanhou as mudanças por que passou a cidade, inclusive as desapropriações dos moradores das regiões centrais da cidade e seu deslocamento para o bairro Restinga (Zona Sul). Na década de 1970, Beleza articula, juntamente com colegas do Estaleiro 
Só, um financiamento ${ }^{3}$ para adquirir uma casa na Restinga, na qual vive até hoje. Lá criou os três filhos. Foi técnico em embarcações, professor do SENAI (cargo que o permitiu viajar o estado todo), conselheiro tutelar, gerente regional da FASC, além de integrar a Rádio Comunitária da Restinga (que funcionou de 2000 a 2004), participar de ateliês comunitários, realizar oficinas gratuitas na comunidade, compor conselhos de pais nas escolas e fazer parte de Grupo de Casais e de Jovens na paróquia do bairro, atividades das quais se afastou por divergências várias.

Sabendo um pouco mais sobre sua modesta vida e sua atitude engajada em lutas populares, deve-se retomar a noção de personalidade encenada, já que tal conceito é útil para exemplificar o quanto este contador de histórias, em paralelo com a narração de fatos coletivos (histórias do bairro, da cidade, dos vizinhos), mostra-se através de uma representação de si tão expansiva. Esse personagem do passado a que se tem acesso por sua performance narrativa contrasta, em certa medida, com o José Carlos que nos recebe em sua casa e que, nitidamente, tem um discurso mais aborrecido sobre o presente e muita desconfiança em relação àquelas instituições que deveriam garantir o bem-estar social de sua comunidade. A seguir, transcreve-se um trecho de uma das entrevistas registradas em vídeo, a partir da qual será possível ilustrar os aspectos apontados:

\begin{abstract}
Quando surgiu essa oportunidade do conselho foi que eu acabei me inscrevendo e acabei sendo eleito, né? E acabei ficando duas gestões. E aí comecei a ter gosto por essa coisa do trabalho social, vendo as dificuldades, por que que uma criança era judiada, por que uma família tinha isso, por que que não ia à escola, né? Então isso acabou me trazendo essas informações que eu não tinha, que eu não sabia; $[. . .]^{4} \mathrm{Me}$ deram a incumbência de ser um gerente da FASC. Primeiro, porque os que estavam anteriormente não estavam conseguindo muito dar conta dos programas que tinha. Os programas que tinha não funcionavam, por que o cara não entendia lá, o técnico, a assistente social, a psicóloga, não conseguiam dar conta. Acaba ficando uma coisa muito burocrática, né? Aí acabei eu indo pra lá. Tinha e tem ainda um atendimento que é da região toda, que é de Belém Novo. Aí acabava as pessoas indo pra lá 5 horas da manhã pra fazer uma fila pra ser atendido de tarde. Aí eu disse: "Mas pára um pouquinho! Nos estamos em um atendimento regional, pra humanizar mais o atendimento, e as pessoas vêm às 5 horas da manhã para serem atendidas de tarde! Mas o que é isso, tchê?". Aí cheguei, atendi um cara que eu conhecia, que era o assistente social, e chega o cara: "Não, infelizmente a demanda é maior do que nós podemos atender”. Eu disse: “Olha, meu velho, se é esse o problema...”. Na época,
\end{abstract}

\footnotetext{
${ }^{3}$ Articulação esta narrada por Beleza (Registro Audiovisual. 11 out. 2007), com amplo destaque a suas capacidades de mobilização dos colegas e enfrentamento dos superiores.

${ }^{4}$ Entre colchetes estão registrados os cortes de trechos considerados desnecessários para a ilustração da questão pretendida, bem como minhas intervenções. As reticências fora dos parênteses indicam hesitação na fala e/ou desvio de assunto. Os trechos entre aspas indicam quando Beleza deixa de narrar a história e passa a reproduzir (em discurso direto livre) a fala do outro, inclusive com mudança de entonação da voz e imitação de seus trejeitos estereotipados.
}

Iluminuras, Porto Alegre, v.12, n. 29, p. 164-178, jul./dez. 2011 
eu era conselheiro. Aí vem aquele problema: dá para resolver o problema? Dá, mas é aquela bateção de boca. Resultado: aí eu fui dizer pra presidente da FASC, na qualidade de conselheiro, fui lá dizer: "Olha, vim aqui conversar contigo porque, antes de eu ir pra Justiça dizer que vocês não estão fazendo nada, que o teu técnico lá ta fazendo um monte de bobagem, eu vim aqui conversar contigo e te dizer assim, assim, assim... Eu acho que, se a demanda está muito grande, a gente tem que arrumar outros meios. Se não tem como resolver, há outras formas de resolver a demanda, mas, agora, o que nós não podemos mais é deixar as pessoas aqui, às 5 da manhã pra ser atendidas de tarde". [Resposta da presidente da FASC:] "Mas o que que está acontecendo?" [Beleza:] "O que, mas tu é a presidente e não tá sabendo disso aí?" A mulher ficou louca. Aí aconteceu um episódio no conselho, na época que eu tava trabalhando. Eu resolvi não ficar até o fim da minha gestão, vim embora porque eu estava no meio de um bando de maluco lá. [...] Eu nunca me esqueço até hoje, uns já me conheciam, e um cara: "Bah, vai acabar essa moleza de vocês. O Beleza vem aí, vocês vão ter que andar nos trilhos!". Mas cada um de nós tem uma postura, né? Meu primeiro ato foi dizer: "A partir de hoje, não tem mais fila. Se tiver, vamos entrar madrugada adentro até atender todo mundo". (Registro Audiovisual. 18 set. 2006)

Na sequência, há um longo relato sobre todos os demais "atos" de Beleza que, segundo conta, mudaram completamente, para melhor, o atendimento na Fundação de Assistência Social e Cidadania (FASC).

Ao contrário do que, talvez, nós pesquisadores, esperávamos, Beleza não narra sequencial e cronologicamente sua gestão na assistência social. Não refere datas, se era rentável, se hesitou em algum momento diante do novo desafio, omite detalhes que poderiam ser interessantes, tampouco refere, ainda que abrangentemente, os dois anos dessa experiência. $\mathrm{O}$ que ele apresenta é uma narrativa fragmentada, permeada pelo discurso do outro acerca das competências dele próprio. Sua estratégia é apresentar a crise, exagerando o detalhismo sobre o que não está bom (má vontade, chefes omissos, excesso de demanda, ameaça de denúncia à Justiça), para que o sucesso de sua intervenção seja percebido por seus interlocutores como o reflexo de seu caráter, de sua força, a tal ponto que sua fama se espalha (“O Beleza vem aí, vocês vão ter que andar nos trilhos").

De certa forma, essa representação de si ganha intensidade na medida em que ele mede forças, e vence o embate, não com vizinhos ou colegas, mas com aqueles que estão no poder (assistentes sociais, técnicos, diretora da FASC). Ao lado desse sujeito que enfrenta e "faz acontecer" de um homem que desiste diante da convivência difícil com colegas não tão engajados

\footnotetext{
${ }^{5}$ Outro caminho de análise viável é considerar as narrativas de Beleza naquilo que elas se aproximam das estruturas arquetípicas (Durand, 2002), já que o narrador explora o tradicional conflito entre o herói e a situação, e a redenção daquele.
}

Iluminuras, Porto Alegre, v.12, n. 29, p. 164-178, jul./dez. 2011 
("Eu resolvi não ficar até o fim da minha gestão, vim embora porque eu estava no meio de um bando de maluco lá.”).

Ciente de que é visto, de que há uma expectativa acerca de suas histórias, cenas do passado se fazem presentes. O efeito desse processo, de certa forma, tende a solidificar a identidade desse informante, constituída pelo ato enunciativo e pela história de vida. O passado torna-se ação, tal como Bergson (2010: 84-85) define:

Enquanto meu corpo, considerado num instante único, é apenas um condutor interposto entre os objetos que o influenciam e os objetos sobre os quais age, por outro lado, recolocado no tempo que flui, ele está sempre situado no ponto preciso

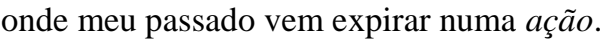

\section{Guardados de memória}

Tendo em vista que as lembranças de Beleza são narradas, em muitos momentos, pela evocação do outro no seu discurso e que a memória é expressa por fragmentos e ressignificações dos fatos passados, é importante focar como essas lembranças vêm à tona. Já que não há um direcionamento rígido através de perguntas específicas, ${ }^{6}$ pode-se dizer que Beleza antevê um roteiro do que pretende contar, dos acontecimentos do passado que evoca?

Os encontros baseiam-se em uma conversa livre, casual, aberta, resultado de alguns anos de convivência com os pesquisadores no seu espaço doméstico. Como, originalmente, pretendia-se obter histórias sobre a fundação do bairro, Beleza começa relatando alguns fatos a esse respeito, mas muito rapidamente parte de um evento coletivo para se ater a divagações e memórias individuais. Por um lado, rememora fatos de sua vida a partir de um aspecto social que o grupo está discutindo (como a narração da época de gerente regional da FASC, que foi motivada pelos comentários sobre as atuais práticas do Conselho Tutelar). Por outro, as lembranças são provocadas quando ele compartilha seus "guardados" com o grupo, um conjunto de recortes, escritos, fotos, desenhos, objetos, imagens e símbolos que ele recolheu ao longo da vida e que guarda como o repositório de suas memórias, a prova material de suas experiências de vida, os "rastros" (Ricouer, 1997) que ajudam a compor o passado na narrativa.

\footnotetext{
${ }^{6} \mathrm{Na}$ verdade, mesmo que tentemos direcionar a conversa ou façamos uma pergunta, Beleza tende a ignorá-las. Isso deixa evidente a "autonomia" de sua memória, em favor de uma organização do pensamento exclusiva. Ao mesmo tempo em que organiza esteticamente seu discurso para prender a atenção dos interlocutores, estes têm mínima influência sobre a seleção dos eventos narrados.
}

Iluminuras, Porto Alegre, v.12, n. 29, p. 164-178, jul./dez. 2011 
É assim que, em quase todos os encontros, Beleza recebe o grupo em sua casa, compartilha seu espaço privado, aloca as pessoas em torno dele e, quase solenemente, dirige-se ao armário e volta com uma pilha de arquivos, organizados sob uma lógica e um grau de importância próprios. Senta-se diante desse material, sob o olhar curioso e expectante de todos, e começa a revolver as folhas esparsas. Na maioria das vezes, o primeiro item que junta é suficiente para uma tarde toda de memórias e histórias. Ao mesmo tempo em que vai contando a história daquele pedaço de papel, faz pausas significativas, como que a lembrança (materializada em um sorriso saudoso) o levasse ao devaneio. Olha, contempla, revive, certamente, as experiências evocadas. Quando retoma o turno da fala, demonstra claramente o interesse de compartilhar suas memórias e vivências:

Aqui uma agenda, é uma agenda das pessoas que eu tinha mais próximas de mim. Tem o nome das pessoas, telefone, quem era, o endereço. Depois, ia botando. Não ficava só pra mim, eu passava para os outros também. Nunca fui muito egoísta nesse ponto. [lê::] "Comissão de cultura". Faziam um panfletinho, eu mostrava: "Tá aqui ó. Minha contribuição tá aqui. Querem?”. Eu dava uma cópia e ficava com uma para mim. E assim vai. Esse aqui é 27 de agosto de 2007 [pega um pedaço de papel $e$ mostra]. Era um... A gente queria fazer um... Fazer um registro, criar uma identidade própria, um registro, né? [...] O que tu fala não é o que tu escreve. Tem mais cuidado. O que vem na boca sai, depois tu vai pensar. Escrever tem que pensar. (Registro Audiovisual. 06 set. 2007)

A importância de apreender fisicamente o passado através desses resquícios de contato com o outro tem no registro escrito sua marca maior ("O que tu fala não é o que tu escreve."), como se a memória pudesse ser totalmente dominada e prontamente acessada através do acesso aos arquivos. É por esse contato com os "guardados" que se pode notar mais claramente o distanciamento do tempo presente e a imersão no tempo subjetivo da memória.

É digno de referência o fato de que Beleza tenha escolhido a própria casa, e não um dos muitos espaços públicos disponíveis para reuniões, para os encontros. Uma explicação provável talvez esteja associada ao fato de que "a casa abriga o devaneio, a casa protege o sonhador, a casa permite sonhar em paz" (Bachelard, 2008: 26), lugar onde se está à vontade para dar vazão às imagens que vão se constituindo e que reúne as memórias do passado e traz, ainda, a marca desse passado.

No entanto, por mais familiar que seja esse espaço, Beleza não foca suas histórias de vida familiar (mais uma vez, como nós, pesquisadores, esperávamos), mas 
segue na evocação de memórias associadas ao coletivo (sua intervenção no espaço público). Bachelard (2008: 97) já alertava sobre esse tipo de postura: “A lembrança pura, imagem que é exclusivamente nossa, não queremos comunicá-la. Dela só confiamos detalhes pitorescos". Por maior que esteja o vínculo estabelecido, não nos é dada a conhecer a lembrança mais íntima. Somos, então, privados da memória doméstica. Pouco sabemos sobre o que está mais perto de nós. Por outro lado, conhecemos muitos detalhes das práticas sociais do Beleza. Há, de fato, um caráter seletivo e afetivo vinculado à narração das lembranças e a seus significados para o sujeito.

O não-dito, de certo modo, também nos está comunicando algo sobre a constituição desse sujeito, que se mostra em partes, que privilegia determinados planos de sua constituição como indivíduo. Assim, retomando a cena do armário que se abre diante de nós, é possível associá-lo à metáfora de Bachelard: "Mas o verdadeiro armário não é um móvel cotidiano. Não se abre todos os dias. Da mesma forma a chave, de uma alma que não se entrega, não está na porta". A "chave", propriedade do Beleza, nos possibilita, na posição de Outro, acessar somente parte de suas memórias, especificamente aquelas que contribuem para a imagem dele como herói social.

O predomínio das narrativas de eventos de vida associados ao coletivo (atuação social) constrói um sujeito a partir de sua interação com o outro. Mesmo quando fala de como é admirado pelos filhos, isso se dá pelo relato de suas práticas fora da casa:

Lá no Panambi, uma vez eu fiz umas coisas lá. Lá eles fazem uma festa, um tipo
dum kerb. Aí eles foram lá preparar e, quando eu vi, veio um carrinho destes de
carregar mala em rodoviária: "Ó, aqui de presente do fulano uma torta de quesco".
Quesco é uma torta de amendoim. Bah, tu tem que ver como é bom. Eu cheguei de
madrugada em casa, em Porto Alegre. Meus filhos ficavam quase loucos, eu sempre
trazia um negócio. Eles faziam questão de dar isso. O cara da empresa... da..., lá
tinha Ernesto Heinz e Esquadrias Saur, umas quatro, cinco empresas lá. E o cara:
"Não, não, o senhor não vai de ônibus. Eu vou devolver o dinheiro da passagem para
o senhor e nós vamos levar o senhor em casa". Foi aí que me trouxeram o carrinho
esse, com torta de quesco, torta não sei do que mais, três ou quatro, todas
encaixotadinhas. É uma coisa interessante, né? (Registro Audiovisual. 08 nov. 2007)

Este episódio, narrado parodiando o sotaque alemão, mais uma vez, apresenta Beleza em sua posição de deferência, o respeito e a estima que provoca, mas contado sob a perspectiva do outro, não dele próprio ("Não, não, o senhor não vai de ônibus. Eu vou devolver o dinheiro da passagem para o senhor e nós vamos levar o senhor em casa”.). Não se tem qualquer referência sobre o porquê dessa cortesia. Isto foi contado 
quando o grupo falava sobre pontos turísticos do interior do Rio Grande do Sul. Esta foi a "deixa" para tal intervenção, que, além de tudo, mostra como os filhos eram contemplados pela posição do pai como funcionário do SENAI que viajava a muitos lugares: sempre havia a recompensa ("Meus filhos ficavam quase loucos, eu sempre trazia um negócio.”). Na verdade, essa “deixa”, ou seja, a escolha de uma oportunidade, dentro da conversa coletiva, para introduzir uma lembrança pessoal é o que Certeau (2008: 162) define como "ocasião":

Sob a sua forma prática, a memória não possui uma organização já pronta de antemão que ela apenas encaixaria ali. Ela se mobiliza relativamente ao que acontece - uma surpresa, que ela está acostumada a transformar em ocasião. Ela só se instala num encontro fortuito, no outro.

Beleza aproveita muito as "ocasiões", a ponto de que toda sua fala que evoca memória está estritamente contextualizada, impulsionada até, pela conversa coletiva, nem sempre organizada e compreensível, à qual é dada coesão, de certa forma, justamente pela inserção desses momentos de reflexão e volta ao passado. Como defende Wagner (1979: 17): "De acordo com a teoria fenomenológica, cada indivíduo constrói o seu próprio 'mundo'. Mas o faz com o auxílio de materiais e métodos que lhe são oferecidos por outros: o mundo da vida é um mundo social que, por sua vez, é preestruturado para o indivíduo".

Um recurso que Beleza utiliza comumente e que é um indicativo para que o grupo interrompa a conversa paralela e concentre atenção em sua fala é o "Eu, por exemplo". Toda sua reivindicação social, manifestação de descontentamento ou crítica é embasada em uma narrativa exemplar, baseada em suas experiências de vida, como se pode perceber nesses dois trechos:

Eu, por exemplo, morava lá em Osório. Eu trabalhava numa olaria de tijolo. A gente ia de bicicleta. Saía 5 horas da manhã de casa. Atravessava um entroncamento que tem ali: vai pra Osório, Tramandaí, Torres. Um entroncamento grande que tem. Agora passou a freeway por cima. Mas ali, quando deu o negócio do Golpe Militar, os militares montaram uma base ali. Ali tinha canhão, helicóptero, e todo mundo que passava ali, inclusive mosquito, tinha que tirar a roupa, senão não passava. Bicicleta, esvaziavam os pneus para ver o que tu tinha dentro. Era assim. Eu ia trabalhar às 5 horas da manhã, tinha que descer. Eles olhavam tudo, vianda... Olhavam lá: tinha feijão, arroz, botava a mão dentro e faziam tu virar no chão. Eles faziam assim. E esse era o exército. (Registro Audiovisual. 01 nov. 2007) 
Eu, por exemplo, estudei muita coisa de leitura, essas coisas, por minha vontade, por causa da minha avó. Minha avó era daquelas, nós era criança, nós ficávamos à beira do fogão, ela puxava um livro lá e começava a ler. Por quê? Ela tava lendo, primeiro, porque a gente era criança, né, mas o que ela tava fazendo? Depois, mais adiante, os que tavam maiorzinhos. já tavam lá adiante, ela abria o livro lá, pra aqueles lerem pros outros. Minha avó fazia isso, e eu me sentia... De certa forma me incentivava a descobrir as coisas, né? (Registro Audiovisual. 23 ago. 2007)

No primeiro caso, a referência à infância e aos desmandos dos militares como forma de justificar o argumento de que, hoje em dia, as pessoas podem reclamar seus direitos, mas, no passado, no tempo da infância, havia submissão e respeito, mesmo aos mais escusos atos dos militares ("botava a mão dentro e faziam tu virar no chão. Eles faziam assim. E esse era o exército"). Note-se que, mesmo sendo um episódio tenso, se considerarmos a situação de uma criança cruzando o caminho do exército, tendo que trabalhar duro (numa olaria), sair cedo de casa, o acontecimento tem ares jocosos, na medida em que "todo mundo que passava ali, inclusive mosquito, tinha que tirar a roupa, senão não passava". O tempo da infância também é descrito em comparação com o tempo presente e as mudanças pelas quais o espaço passou: "Atravessava um entroncamento que tem ali: vai pra Osório, Tramandaí, Torres. Um entroncamento grande que tem. Agora passou a freeway por cima”. A calma e a liberdade da infância, temporariamente interrompidas pela presença dos militares, em oposição ao agito da violência da freeway (que passa por cima!) no tempo presente.

No segundo caso, mais uma vez, a referência ao tempo da infância, a convivência com os avós, a vida das crianças, o tempo que passa devagar. Essa memória é trazida à tona cheia de questionamentos, de perguntas retóricas ("por quê?", "mas o que ela tava fazendo"?), para exemplificar como a educação de hoje é falha, como as crianças são privadas do saber e das experiências dos antigos. Sob outra perspectiva, Beleza aqui se apresenta como aquele que é apto agir na sociedade (inclusive para criticar o ensino convencional) porque sua infância foi exemplar, no sentido de que pôde experimentar os efeitos de uma sabedoria que não mais é valorizada nos dias atuais.

Por vários caminhos e com vários significados, Beleza escolhe, seleciona e compartilha suas experiências, com a intenção de, pela mediação da linguagem, "transcender o aqui e agora" e "tornar presente uma grande variedade de objetos" (Berger; Luckmann, 1983: 59-60). A partir desses fragmentos, vai compondo a si mesmo na relação com o outro. 


\section{Exercício de etnografia}

Em vários momentos já se abordou, ainda que tangencialmente, a participação, a interferência e as expectativas dos pesquisadores em relação às narrativas do Beleza. Muito disso se deve ao vínculo criado no grupo pelos anos de convivência. A aproximação com o "objeto de estudo" permite que seja suprimida a deferência "Senhor", em favor de uma liberdade que nos permite usar simplesmente "Beleza", "o Beleza”. A filmadora (na época, ainda não digital) possibilitava o registro de um terço do encontro, tempo que a fita podia armazenar. O restante do tempo, sem a sensação de "estar sendo filmado", não tinha nenhuma implicação no modo como Beleza desempenhava sua performance.

O companheirismo estabelecido tem implicações, principalmente porque, quanto mais nos aproximamos, mais nos envolvemos com os projetos pessoais e sociais dele. Atualmente, foi estabelecido certo "contrato verbal": Beleza consente em compartilhar seu tempo e suas narrativas, desde que nós, como representantes da Universidade Pública, reservemos um tempo para ajudá-lo a multiplicar as narrativas da Restinga no próprio bairro, nas escolas.

Por um período, todos os pesquisadores (coordenadora do projeto, alunos de graduação e pós-graduação) realizavam, cada um, seus registros escritos durante os encontros, o que, muitas vezes, fazia Beleza interromper a narrativa e "esperar" que voltássemos a atenção a ele. Afinal, que memória pode ser compartilhada se ninguém ouve, todos escrevem? Foi necessário rever nossa postura de escuta, portanto. Continuamente esse processo de interação/intervenção é repensado pelos componentes do grupo de pesquisa: para quem Beleza narra? Para nós? Para si? Para os moradores do bairro? Qual a influência de saber que se está sendo filmado? Como traduzir o tempo narrado do Beleza? É preciso escrever o que já está registrado em vídeo?

Parte dessas questões encontra respaldo na noção de que não há como não estabelecer um trabalho em parceria, cuja presença do pesquisador nunca poderá ser apagada ou ignorada: "a escrita etnográfica, ao configurar-se na própria tríade autor/tradutor/texto, proporciona, ao antropólogo, a sistematização de seus pensamentos interiores e a construção de ações estáveis em relação à cultura e à sociedade pesquisadas" (Eckert; Rocha, 2003: 38-39). No campo dos estudos de literatura, a prática etnográfica como um dos principais meios de acesso à complexidade da 
narrativa em contexto de oralidade atende à necessidade interdisciplinar desse tipo de pesquisa com foco na linguagem e nas relações sociais estabelecidas pelo indivíduo.

Todo o "material bruto" produzido pelas muitas horas de encontros e entrevistas, ao ser analisado, é inevitavelmente editado segundo os interesses de cada pesquisador diante dessas informações. Nesse sentido, o próprio pesquisador recompõe a trajetória do informante sob uma perspectiva tendenciosa, mais objetiva (sem dispersões), organizada, linear. Dá (outra) forma a um conjunto de histórias, elimina aquilo que considera supérfluo ao seu propósito, reconfigura o vivido. Em certa medida, é conarrador.

Para finalizar, remetendo a Benjamin (1994) e a sua advertência sobre a morte das narrativas, pôde-se perceber, nesse tempo de pesquisa, que, de fato, as experiências estão deixando de ser comunicadas. Mas, principalmente, o tempo da escuta está desaparecendo. Narradores como Beleza, persistentes em querer compartilhar suas histórias e refazer o trajeto de suas vidas, estão cada ver mais escassos. Se é pela narrativa, pela interação com o outro, que o sujeito se constitui, então se pode questionar o quanto se está perdendo sem esse exercício de subjetividade.

A partir das reflexões aqui apresentadas e da análise das histórias de vida de Beleza, ficou evidente o jogo de memória entre lembrar e esquecer. A lembrança está a serviço da elaboração simbólica do próprio sujeito. Essa elaboração visa a uma estetização da memória - com vistas a mostrar ao outro aquilo que se pretende, mas de uma forma poética, com um arranjo especial.

Beleza empenha-se na construção ética de si ao priorizar as histórias de sua vida que o destacam como um agente atuante, funcional e elementar na sociedade, é o seu modo de lembrar. Um exemplo, um espelho. Sua memória "é essa magia vicariante pela qual um fragmento existencial pode resumir e simbolizar a totalidade do tempo reencontrado" (Durand, 2002: 403).

\section{Referências}

BACHELARD, Gastón. A poética do espaço. $2^{\mathrm{a}}$ ed. São Paulo: Martins Fontes, 2008. A dialética da duração. São Paulo: Ática, 1988.

BARROS, Myriam Lins de. "Memória e família". In: Estudos históricos, v. 2, n.3. Rio de Janeiro: CPDOC/FGV, 1989. p.29-42.

BENJAMIN, Walter. Magia e técnica, arte e politica. $7^{\mathrm{a}}$ ed. (Obras Escolhidas I). São Paulo: Brasiliense, 1994. 
BERGER, Peter L.; LUCKMANN, Thomas. "Os fundamentos do conhecimento na vida cotidiana". In: A construção social da realidade. 5. ed. Petrópolis, Rio de Janeiro: Vozes, 1983. p.35-68.

BERGSON, Henri. Matéria e memória: ensaio sobre a relação do corpo com o espírito. 4. ed. São Paulo: Martins Fontes, 2010.

BOSI, Ecléa. Memória e sociedade: lembrança dos velhos. $3^{\mathrm{a}}$ ed. São Paulo: Cia das Letras, 1994.

CERTEAU, Michel de. A invenção do cotidiano: artes de fazer. $15^{\mathrm{a}}$ ed. Petrópolis, Rio de Janeiro: Vozes, 2008.

DURAND, Gilbert. As estruturas antropológicas do imaginário. $3^{\mathrm{a}}$. ed. São Paulo: Martins Fontes, 2002.

ECKERT, Cornelia. "Questões em torno do uso de relatos e narrativas biográficas na experiência etnográfica”. In: Humanas, Revista do IFCH, v. 19-20, n. 1-2. Porto Alegre: UFRGS, 1996-1997. p.21-44.

ECKERT, Cornelia; ROCHA, Ana Luiza Carvalho da. O tempo e a cidade. Porto Alegre: Editora da UFRGS, 2003.

GOFFMAN, Erving. A representação do eu na vida cotidiana. $8^{\mathrm{a}}$ ed. Petrópolis, Rio de Janeiro: Vozes, 1999.

HALBWACHS, Maurice. A memória coletiva. São Paulo: Centauro, 2006.

POLLAK, Michael. "Memória, esquecimento, silêncio". In: Estudos históricos, v. 2, n.3. Rio de Janeiro: CPDOC/FGV, 1989. p.3-15.

RICOUER, Paul. Tempo e narrativa. (Tomo I). São Paulo: Papirus, 1994.

Tempo e narrativa. (Tomo III). São Paulo: Papirus, 1997.

VELHO, Gilberto. Projeto e metamorfose: antropologia das sociedades complexas. $2^{\mathrm{a}}$ ed. Rio de janeiro: Jorge Zahar, 1999.

WAGNER, Helmut R. "A abordagem fenomenológica da sociologia". In: (org.). Fenomenologia e relações sociais: textos escolhidos de Alfred Schutz. Rio de Janeiro: Zahar Editores, 1979. p.3-50.

Recebido em: 16/12/2010

Aprovado em: 25/03/2011 